ks. dr Grzegorz Wąchol ${ }^{1}$

ORCID: 0000-0002-6427-7231; grzegorz.wachol@upjp2.edu.pl

Uniwersytet Papieski Jana Pawła II w Krakowie

\title{
Posługa duszpasterska w środowisku osób zaburzonych psychicznie. Aspekty pastoralne
}

\section{Streszczenie}

Szacuje się, że ponad 5 proc. mieszkańców Europy jest dotkniętych depresją, ponad 4 proc. zaburzeniami lękowymi, a ogólny wzrost chorób psychicznych w latach 2005-2015 wyniósł 16 procent. Połowa wszystkich mieszkańców Starego Kontynentu przynajmniej raz w życiu będzie cierpieć na zaburzenia psychiczne. Dlatego Kościół powinien podjąć refleksję nad duszpasterstwem takich osób. W przygotowaniu do korzystania z sakramentów duże znaczenie ma współpraca duchownego z pozostałym personelem szpitala, szczególnie asystentami pastoralnymi. $\mathrm{W}$ artykule zostanie zwrócona uwaga na ogólne aspekty wsparcia duszpasterskiego pacjentów z zaburzeniem psychicznym oraz zaprezentowana droga przygotowania takich osób do korzystania ze spowiedzi i Eucharystii.

Słowa kluczowe: zaburzenie psychiczne, kapelan, asystent pastoralny, sakramenty

\section{Abstract}

The Chaplain's Ministry in a Mentally Disturbed Environment. Pastoral Aspects

It is also estimated that over 5 percent of Europeans are depressed, over 4 percent are affected by anxiety disorders, and the overall increase in mental illness in 2005-2015 was 16 percent. Half of all inhabitants of the Old Continent will suffer from mental disorders at least once in their life. Therefore, the Church should reflect on the pastoral care of such people. In the preparation for the use of the sacraments, the cooperation of the clergyman with other hospital staff, especially pastoral assistants, is of great importance. The article draws attention to the general aspects of pastoral

1 Ks. Grzegorz Wąchol - prezbiter archidiecezji krakowskiej, doktor nauk teologicznych; praca doktorska pt. Wsparcie duszpasterskie uzależnionych od alkoholu w procesie leczenia (2020), asystent w Katedrze Teologi i Psychologii Pastoralnej Wydziału Teologicznego UPJPII i kapelan Szpitala Klinicznego im. dr. J. Babińskiego w Krakowie. 
support for patients with mental disorders and presents how such persons should prepare for confession and the Eucharist.

Keywords: mental disorder, chaplain, pastoral assistant, sacrament

Osoby psychotyczne bardzo często należą do społecznej kategorii wykluczonych. Na takie podejście składa się wiele czynników takich, jak: niemożność samodzielnego decydowania o własnej osobie, specyficzne rozumienie świata, nieadekwatność zachowania do sytuacji, poruszanie treści, które wydają się zupełnie nierealne i oddalone od rzeczywistości. Kościół powinien dostrzegać potrzeby tych wiernych, którzy przeżywają cierpienie i działać na rzecz poprawy jakości ich życia, szczególnie w sferze duchowej i osobowej. Duże znaczenie w tej kwestii ma praca kapelanów ośrodków, gdzie takie osoby podejmują leczenie.

\section{Miejsce osób z zaburzeniami psychicznymi w Kościele}

W Starożytności osoby dotknięte zaburzeniami psychicznymi próbowano leczyć różnymi metodami, najczęściej z pogranicza medycyny naturalnej i magii. Wraz z rozpowszechnieniem się chrześcijaństwa odchodzono od takich praktyk i zaczęto traktować chorych psychicznie podobnie jak ubogich, żebraków i wędrowców. Kościół od początku pielęgnował tradycję opieki nad chorymi, których otaczał nie tylko modlitwą, ale również kompleksowym leczeniem (w miarę możliwości danej epoki). Wczesne źródła sugerują istnienie szpitali i miejsc opieki nad chorymi (również psychicznie) już od IV wieku na terenie całego Cesarstwa Bizantyjskiego ${ }^{2}$. Wbrew powszechnej opinii dopiero pod koniec średniowiecza zaczęto postrzegać takie osoby jako opętane przez złe moce $^{3}$. W związku z tym powierzano je w opiekę instytucjom kościelnym, w których, często zbyt pochopnie przeprowadzano egzorcyzmy ${ }^{4}$. Obok

2 Por. G. Androutsos, M. Karamanou, The hospital institutions of Byzantium and the hospital (Xenon) of Pantokrator monastery in Constantinople, „La Presse Médicale” 41 (2012) nr 1, s. 68-73. B. Seyda, Dzieje medycyny w zarysie, Warszawa 1977, s. 88.

3 Por. A. Hącia, Psychiatra i jego misja w nauczaniu Kościoła, Lublin 2017, s. 29-38.

4 Por. M. Ficoń, Postrzeganie osób chorych psychicznie przez pryzmat historii, w: Odnaleźć wykluczonych, red. J. Dziedzic, J. Klimek, Kraków 2014, s. 81-88. 
takiego podejścia wyróżniali się myśliciele chrześcijańscy podkreślający, że choroba psychiczna nie ma genezy w opętaniu. Należeli do nich m.in. Piotr Abelard i John Salisbury ${ }^{5}$. Powszechne, głębsze i całościowe spojrzenie na człowieka, które rozwinęło się wraz z rozkwitem myśli humanistycznej, przyniosło postrzeganie zaburzeń psychicznych jako choroby wymagającej leczenia ${ }^{6}$. W ten paradygmat wpisywały się głównie zakony chrześcijańskie tworzące miejsca, gdzie leczono chorych z różnymi dolegliwościami, w tym psychicznymi. Największe zasługi na tym polu działalności zyskały: zakon mercedarianów, który już w 1410 roku w Hiszpanii założył jeden z pierwszych szpitali dla obłąkanych, Zakon Szpitala Najświętszej Marii Panny Domu Niemieckiego w Jerozolimie (Krzyżacy) posiadający wiele placówek dla chorych w całej Europie oraz bonifratrzy, którzy wyspecjalizowali się w opiece nad chorymi psychicznie, a ich założyciel św. Jan Boży sam przeżył epizod psychotyczny ${ }^{7}$ Także współczesne nauczanie Kościoła powszechnego i Kościołów partykularnych wskazuje na obowiązek otaczania ludzi z dysfunkcjami psychicznymi troskliwą opieką duszpasterską8.

Obok przygotowania do uczestnictwa w sakramentach, bardzo ważnym zadaniem duszpasterza wobec takich osób jest wielowymiarowe wspieranie ich, a zwłaszcza próba destygmatyzacji, czyli zmiany podejścia i sposobu powszechnego myślenia o tej grupie społecznej. Osoby z zaburzeniem psychicznym budzą pewną fascynację, co niekiedy wykorzystują twórcy kultury i dziennikarze, kreując cierpiących psychicznie na głównych bohaterów różnych dzieł artystycznych bądź medialnych przekazów. Jednocześnie obserwowany jest społeczny dystans związany z lękiem względem takich ludzi, postrzeganie ich jako gorszych obywateli i przypisywanie im pejoratywnych określeń, jako osobom

5 Por. L. Zegnas, B. Victor, Conceptual Issues in history of Psychiatry, w: Review of Geeral psychiatry, ed. H.H. Goldman, Los Altos 1984, s. 10.

6 Por. M. Ficoń, Postrzeganie..., dz. cyt., s. 81-88.

7 Por. Z. Pochmara-Wysoczyńska, Bonifratrzy i ich posługiwanie, Kraków 2017, s. 47-56. A. Hącia, Psychiatra..., dz. cyt., s. 41-49.

8 Por. J. Klimek, Duszpasterstwo..., dz. cyt., s. 193-211. 
problematycznym ${ }^{9}$. W konsekwencji sami chorzy popadają w negatywne uczucia względem siebie, co często przeradza się w proces autostygmatyzacji (self-stigma), nazywanej też drugą chorobą, opartej na efekcie przewidywanego odrzucenia ${ }^{10}$. Wynikiem tego jest kurczenie się sieci społecznej (social-network) wokół chorego i jego rodziny oraz pogarszanie się stanu psychicznego ${ }^{11}$. Te spostrzeżenia potwierdzają badania. Chorzy psychicznie są stereotypizowani i najczęściej utożsamiani z osobami niebezpiecznymi, agresywnymi, nieprzewidywalnymi ${ }^{12}$. Skutkiem tego, co potwierdza ankieta ośrodka badań CBOS z 2012 roku, chorzy psychicznie odczuwają przede wszystkim wstyd ze względu na swoją sytuację zdrowotną i na postrzeganie ich przez otoczenie ${ }^{13}$. Z innych badań CBOS opublikowanych w latach 2000 i 2008 wynika, że odsetek życzliwie nastawianych osób $\mathrm{w}$ polskim społeczeństwie wobec pacjentów psychiatrycznych zmalał z 71\% w roku 1999 , do $65 \%$ w roku 2008 . W badaniach bardzo często (ponad 60\% odpowiedzi twierdzących) chorzy psychicznie są opisywani w sposób pogardliwy i obraźliwy ${ }^{14}$. Towarzyszenie duchowe i wsparcie duszpasterskie, szczególnie w okresie hospitalizacji lub podjętej terapii, mogą wzbudzić w nich motywację do podjęcia próby zmiany myślenia o sobie samych i zbudowania pozytywnego obrazu własnej osoby ${ }^{15}$. W procesie zdrowienia i w czasie remisji ważną rolę odgrywa

9 Por. D. Sozańska, Między fascynacją a dystansem. Społeczny odbiór osób chorych psychicznie a ich wizerunek $w$ kulturze masowej - analiza wybranych przypadków, „Labor et Educatio” 2 (2014), s. 105-117.

10 Por. A. Ucok, D. Brohan, N. Sartorius, M. Leese, C. Yoon, Anticipated discrimination among peaple with schizophrenia, „Acta Psychiatrca Scandinaviensis” 1 (2011) no. 125, s. 77-83.

11 Por. J. Klimek, Duszpasterstwo..., dz. cyt., s. 292-294; A. Cechnicki, A. Wojciechowska, M. Valdes, Sieć społeczna a jakość życia osób chorujących na schizofrenię w siedem lat po pierwszej hospitalizacji, „Psychiatria Polska” 41 (2007) nr 4, s. 527-537.

12 Por. M.C. Angermeyer, H. Matschinger, The stigma of mental illness: effects of labelling on public attitudes towards people with mental disorder, "Acta Psychiatrica Scandinaviensis” 2003 (108) no. 4, s. 304-309.

13 Por. Centrum Badania Opinii Społecznej, Stosunek do osób chorych psychicznie, Warszawa 2012, s. 2-3.

14 Por. B. Wciórka, J. Wciórka, Osoby chore psychicznie w społeczeństwie. Komunikat z badań CBOS, Warszawa 2008.

15 Por. P. Koza, Reintegracja psychiczna w aspekcie filozoficznym, w: Odnaleźć wykluczonych, red. J. Dziedzic, J. Klimek, Kraków 2014, s. 115-128. 
osobiste zaangażowania się chorego w odzyskiwanie kontroli nad swoim życiem i aktywne przeciwstawienie się stygmatyzacji. W procesie umacniania (empowerment) w obliczu choroby, chory psychicznie może sam stać się dla siebie oparciem ${ }^{16}$. Dodatkowym czynnikiem, o który należy zadbać, to przywrócenie nadziei na normalne funkcjonowanie i wyjście z choroby. Oba czynniki mają często mocne ufundowanie w doświadczeniu religijnym pacjenta i tej okazji nie wolno zmarnować. Opinie specjalistów dają pozytywne rokowania i duże szanse powrotu do zdrowia (w tym przypadku jego definicja jest bardzo rozbieżna, ale przyjmuje się za nią stan, w którym osoba dotknięta zaburzeniem może względnie samodzielnie funkcjonować w społeczeństwie), nawet w tak ciężkich zaburzeniach psychicznych jak schizofrenia ${ }^{17}$.

Kolejnym istotnym zadaniem, wynikającym z uwzględnienia duchowego wymiaru osób z zaburzeniem psychicznym, jest odróżnienie takiego stanu od opętania. Trans i opętanie (F44.3) jako zjawisko chorobowe zostało sklasyfikowane przez Światową Organizację Zdrowia, a niektóre badania pokazują, że jest powszechnie uznawanym doświadczeniem religijnym w wielu kulturach świata ${ }^{18}$. Duszpasterz, podejmujący współpracę z osobą dotkniętą zaburzeniem psychicznym, powinien być wyczulony na możliwość opętania i znać kryteria rozpoznania tego szczególnego stanu duchowego ${ }^{19}$. Zostały one opracowane przez organizacje zajmujące się zdrowiem psychicznym (Amerykańskie Towarzystwo Psychiatryczne, Światową Organizację Zdrowia) oraz przez Stolicę Apostolską. Strona kościelna zamieściła je w dokumentach Kościoła oraz obrzędzie liturgicznym pt. Egzorcyzmy i inne modlitwy błagalne ${ }^{20}$.

16 Szerzej na ten temat: M. Anczewska,J. Wciórka, Umacnianie-nadzieja czy uprzedzenia, Warszawa 2007.

17 Por. M. Tyszkowa, M. Jarema, Między zdrowiem a schizofrenia, „Psychiatria Polska” 47 (2016) nr 4, s. 587-597.

18 Por. J. Dębiec, Opętanie. Próba psychologicznego ujęcia problemu, Kraków 2004, s. 124.

19 Por. J. Klimek, Duszpasterstwo..., dz. cyt., s. 322-323.

20 Por. J. Dziedzic, Kapelan w obliczu opętania. Terapia czy egzorcyzm?, w: Odnaleźć wykluczonych, red. J. Dziedzic, J. Klimek, Kraków 2014, s. 247-264. 


\section{Pomiędzy medyczną precyzją a pastoralną delikatnością (benignitas pastoralis)}

Wraz z postępem psychiatrii zmieniają się cele i sposoby leczenia pacjentów z zaburzeniami psychicznymi. Wysiłki zespołów medycznych skierowane są dziś ku temu, aby chory osiągnął remisję funkcjonalną i powrócił do swoich ról życiowych. Model leczenia przesuwa się z oddziałów szpitalnych (stacjonarnych i opresyjnych) ku opiece środowiskowej w miejscu zamieszkania chorego (zespoły hospitalizacji domowej) bądź w jego najbliższym otoczeniu (opieka ambulatoryjna, oddziały dzienne) ${ }^{21}$. Towarzyszenie takim pacjentom staje się utrudnione z powodów ograniczonego dostępu do nich oraz oddalenia od miejsca sakralnego, które istotnie wpływa na rozwój duchowości.

Prawidłowe wsparcie duszpasterskie powinno uwzględniać także język, jakim kapłan będzie się posługiwał wobec samych zainteresowanych. Określania tego, co uważane jest za powszechną normę społeczną, a co przynależy do zaburzenia oraz sposób mówienia o osobach dotkniętych tym zjawiskiem, ulegają zmianom. Termin choroba psychiczna posiadający negatywne i stygmatyzujące konotacje, został wycofany z użycia w profesjonalnej nomenklaturze na rzecz sfomułowania zaburzenie psychiczne ${ }^{22}$. Pomimo rozwoju w dziedzinie postrzegania osób z zaburzeniami psychicznymi ciągle trudno jest o jednoznaczną systematykę cech świadczących o tym stanie. Według klasyfikacji Amerykańskiego Towarzystwa Psychiatrycznego (DSM-5) zaburzenia psychiczne dotyczą nieprawidłowości w zachowaniu, regulacji emocji lub czynnościach poznawczych. Są odzwierciedleniem dysfunkcji procesów biologicznych, psychologicznych lub rozwojowych koniecznych do właściwego funkcjonowania psychicznego ${ }^{23}$.

${ }^{21}$ Por. M.I. Cascher, J.D. Bess, Pacjent na oddziale psychiatrycznym. Wskazówki praktyczne, tłum. J. Serewa, M. Pokorska, red. D. Dudek, Warszawa 2013, s. 7.

${ }_{22}$ S. Pużyński, Choroba psychiczna - problemy z definicją oraz miejscem $w$ diagnostyce i regulacjach prawnych, „Psychiatria Polska” 41 (2007) nr 3, s. 299-308.

${ }_{23}$ Por. J. Butcher, J. Hooley, S. Mineka, Psychologia zaburzeń, tłum. S. Pikiel, A. Sawicka-Chrapkowicz, Sopot 2017, s. 29. 
Zaburzenia psychiczne podzielić można na poszczególne kategorie schorzeń, które wykazują podobieństwa w swoim pochodzeniu i przebiegu. Od kilkudziesięciu lat trwają próby ujednolicenia klasyfikacji zaburzeń psychicznych, co zwiększa szanse na właściwą diagnozę i przebieg leczenia ${ }^{24}$. Dla kapłana posługującego osobom z zaburzeniem psychicznym ważne jest, aby znał ogólne zestawienie tych schorzeń, gdyż mają one istotny wpływ na podejście duszpasterskie wobec pacjenta. Najnowsza klasyfikacja chorób Światowej Organizacji Zdrowia ICD-11 wśród zaburzeń psychicznych podaje aż 21 kategorii ${ }^{25}$. Inna ceniona klasyfikacja DSM-5 opracowana przez Amerykańskie Towarzystwo Psychiatryczne opisuje omawiane schorzenia w bardziej syntetyczny sposób, wymieniając: zaburzenia neurorozwojowe, zaburzenia należące do spektrum schizofrenii i inne zaburzenia psychotyczne, zaburzenia dwubiegunowe, zaburzenia lękowe, zaburzenia obsesyjno-kompulsyjne, zaburzenia pourazowe i związane z czynnikiem stresowym, zaburzenia dysocjacyjne, zaburzenia z objawami somatycznymi (pokrewne), zaburzenia jedzenia i odżywiania się, zaburzenia wydalania, zaburzenia snu i czuwania, dysfunkcje seksualne, dysforię płciową (zaburzenia tożsamości płciowej), zaburzenia niszczycielskie, zaburzenia kontroli impulsów i zachowania, zaburzenia związane z substancjami i uzależnienia, zaburzenia neuropoznawcze, zaburzenia osobowości, parafilie ${ }^{26}$.

Dużą trudność stanowi prawidłowa diagnoza, gdyż zmiany w organizmie osoby z zaburzeniem psychicznym często są niejednoznaczne, nietypowe i nieostre ${ }^{27}$. Tym bardziej zewnętrzny ogląd nie pozwala na jednoznaczne rozpoznanie schorzenia. Samo określenie tego, co jest normalne, a co nie, przysparza wiele trudności w życiu codziennym i w badaniu klinicznym. W przypadku próby określania norm przyjętych za prawidłowe bardzo ważną rolę odgrywa kultura i środowisko, w jakim

24 Por. A. Bilikiewicz, Klasyfikacja zaburzeń psychicznych i zagadnienia nazewnictwa, w: Psychiatria. Podręcznik dla studentów medycyny, red. A. Bilikiewicz, Warszawa 2009, s. 108-115.

25 WHO, ICD-11. International Classification of Diseases 11th Revision, https://icd.who.int/ browse11/1-m/en (22.04.2020).

26 Por. H.J. Möller, Możliwości i ograniczenia DSM-5 w polepszeniu klasyfikacji i diagnozy zaburzeń psychicznych, „Psychiatria Polska” 52 (2018) nr 4, s. 611-628.

27 Por. A. Kępiński, Poznanie chorego, Warszawa 1989, s. 6. 
żyje dany człowiek, gdyż one rzutują na sposób podejścia do poszczególnych doświadczeń i typowych (lub nietypowych) reakcji na nie ${ }^{28}$. Martin Seligman, Elaine Walker i David Rosenhan wymieniają siedem zewnętrznie obserwowalnych cech postawy wykraczającej poza normalność. Są to: 1) przeżywane cierpienie, 2) nieprzystosowanie, 3) irracjonalne zachowanie, 4) nieprzewidywalność i brak kontroli, 5) rzadkość i niekonwencjonalność, 6) dyskomfort obserwatora, 7) naruszanie norm ${ }^{29}$.

Wymienione cechy mogą być pomocne do tego, aby zwrócono uwagę na występowanie zaburzenia u osób korzystających ze wsparcia duszpasterskiego poza miejscem świadczącym specjalistyczne leczenie dla takiej kategorii pacjentów. Spotkanie duszpasterskie jest okazją do przyglądnięcia się problemowi, ale musi temu towarzyszyć miłość i łagodnośćc ${ }^{30}$.

W wyniku panujących stereotypów i pobieżnego oglądu zaburzenie psychiczne może zostać pomylone z niepełnosprawnością intelektualną, gdyż osoby dotknięte nią, również w wielu aspektach odbiegają swoją postawą od przyjętych norm kulturowych. Niepełnosprawność intelektualna jest zaburzeniem rozwojowym klasyfikowanym na różne sposoby. Jej podstawowymi cechami są: obniżony poziom ilorazu inteligencji, niezdolność do samodzielnego funkcjonowania społecznego, obniżona sprawność motoryczna oraz problemy w komunikacji z innymi osobami przejawiające się na różnym poziomie: od umiarkowanych, do całkowitej niemożności ${ }^{31}$. Objawy niepełnosprawności intelektualnej uwydatniają się przed wejściem w okres dorosłości i są względnie stale obecne przez całe życie $^{32}$. Niepełnosprawni intelektualnie stanowią odrębną grupę, która również wymaga specjalistycznego wsparcia duszpasterskiego.

28 Por. J. Butcher, J. Hooley, S. Mineka, Psychologia..., dz. cyt., s. 28.

${ }_{29}$ Por. M. Seligman, E. Walker, D. Rosenhan, Psychopatologia, tłum. J. Gilewicz, Poznań 2017, s. 34-35.

$30 \quad$ R. Hajduk, Łagodność pastoralna, Kraków 2018, s. 152-153.

31 Por. S. Baranow, A. Ermer, V. Dittmann, R.D. Stieglitz, Upośledzenie umysłowe w: Kompendium psychiatrii, psychoterapii, medycyny psychosomatycznej, red. H.J. Freyberger, W. Schneider, R.D. Steiglitz, Warszawa 2015, s. 208. J. Błeszyński, Niepełnosprawność intelektualna. Mowa, język, komunikacja, Gdańsk 2013, s. 25-28.

32 Por. M. Rapley, The social construction of intellectual disability, Cambridge 2004, s. 39. 


\section{3. „Duchowy” wymiar psychiatrii}

Psychiatria będąca jednym z działów medycyny, jest postrzegana jako nauka podejmująca kwestie związane ze zdrowiem ciała i umysłu ludzkiego. W ten sposób można pominąć duchowy wymiar człowieka, który również powinien być uwzględniony na drodze wsparcia, celem osiągania przez niego ziemskiego dobrostanu ${ }^{33}$. Etymologia terminu psychiatria łączy w sobie pojęcia greckie: psyche ( $\psi v x \eta ́)$ - duszę, umysł, tchnienie ży-

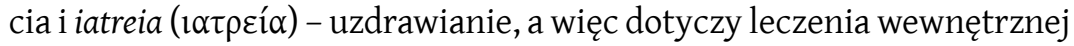
sfery człowieka. Dzisiaj obydwie funkcje są wyraźnie rozdzielone pomiędzy lekarza i duchownego, jednak w praktyce dochodzi do ich spotkania podczas pomocy świadczonej pacjentom, co rodzi pytania o możliwości współpracy i ewolucję samej psychiatrii, jak i duszpasterstwa osób z zaburzeniem psychicznym ${ }^{34}$. Obecnie często można spotkać redukcjonizmy dewaluujące lub pomijające jedną ze stron. $Z$ jednej strony wciąż wielu duszpasterzy postrzega leczenie psychiatryczne w sposób podejrzliwy, jako proces nieprzynoszący pożądanego efektu, a nawet zagrażający religii. $Z$ drugiej strony nie brakuje opinii, w których przedstawia się wiarę ograniczoną jedynie do wymiaru terapeutycznego, nie dostrzegając przy tym wartości nadprzyrodzonych ${ }^{35}$. Według Benedykta XVI zanegowanie wymiaru duchowego odbiera człowiekowi najbardziej podstawowe powołanie do tworzenia relacji z Bogiem, z kolei zupełne lekceważenie psychologii pozbawia wielu narzędzi wglądu w ludzką głębię $e^{36}$. Pomoc duchowa i psychiatryczna powinny być więc ze sobą ściśle powiązane,

33 Por. Jan Paweł II, Encyklika Redemptor hominis, 4.03.1979, Wrocław 1994, 13. Por. J. Grzybowski, Człowiek jako osoba w metafizyce św. Tomasza z Akwinu, „Warszawskie Studia Teologiczne" 16 (2003), s. 201-229.

34 Por. S. Hauerwas, Psychiatric Care: Professional Commitments and Societal Responsibilities, w: On Moral Medicine. Theological Perspectives in Medical Ethics, ed. S.E. Lammesr, A. Verhey, Eerdmans 1989, s. 556.

35 Por. M. Golczyńska, Pracować w zespole, w: Między konfesjonatem a kozetka, red. K. Jabłońska, C. Gawryś, Warszawa 2010, s. 15-16.

36 Por. J. Ratzinger, Prawda w teologii, Kraków 2005, s. 50. J. Ratzinger, Zeitfragen und christlicher Glaube. Acht Predigten aus der Münchener Jahren, Würzburg 1982, s. 84. G. Bachanek, Psychologia a teologia. Miejsca spotkania w antropologicznej refleksjij. Ratzingera, „Studia Teologii Dogmatycznej" 1 (2015), s. 31-47. 
gdyż problemy z obu sfer często są współzależne. Źle przeżywane treści religijne mogą wpływać na pojawienie się kryzysów psychicznych i odwrotnie: zaburzenia psychiczne wpływają na jakość relacji z Bogiem ${ }^{37}$. Jednym z podstawowych zadań duszpasterskich wobec każdego człowieka jest duchowa formacja konieczna do kształtowania właściwego obrazu Boga. To ważne zadanie wobec osób z zaburzeniem psychicznym, jednak sama terapia pozbawiona wsparcia pastoralnego nie wystarczy do osiągnięcia tego celu ${ }^{38}$.

U podłoża właściwego postrzegania obrazu Boga leży koncepcja osoby ludzkiej i sposób rozumienia choroby psychicznej. Andrzej Kapusta postuluje podejście fenomenologiczne do zjawiska zaburzenia psychicznego. Powołując się na definicję psychozy Karla Jaspersa, stwierdza, że każde zjawisko ma swój wyjątkowy sens nawet wtedy gdy ma być on postrzegany w kategoriach „bezsensu”. Współczesny rozwój technologiczny na tyle zmienił oblicze medycyny, że przyczynił się do odejścia od takiego postulatu na rzecz próby jednoznacznego diagnozowania oraz systematycznego opisu poszczególnych jednostek chorobowych. Specyfika pomocy psychiatrycznej domaga się wybitnie zindywidualizowanego podejścia, w którym uwzględnione są również osobiste i duchowe doświadczenia pacjentów ${ }^{39}$. Antoni Kępiński podkreślał też, że wraz z wiekiem maleją zdolności obiektywnego poznania cudzego stanu psychicznego, dlatego dla prawidłowego zrozumienia pacjenta z zaburzeniem psychicznym potrzebne jest humanistyczne podejście, uwzględniające całość jego przeżyć, w tym doświadczenia duchowe ${ }^{40}$, co chrześcijańska koncepcja człowieka uznaje za cechy upodabniające do Boga. Wśród nich starotestamentalna antropologia wymienia: rozumność, wolność, religijność, zdolność do tworzenia relacji i odkrywania

37 Por. S. Urbański, Nieskończoność Boga w mistycznym zjednoczeniu, „Studia Theologica Varsaviensia" 51 (2013) nr 2, s. 17-34. A. Draguła, Duchowość karmi się psychika, w: Między konfesjonałem a kozetka, red. K. Jabłońska, C. Gawryś, Warszawa 2010, s. 13-14.

${ }_{38}$ Por. J. Przybyłowski, Wychowanie i formacja chrześcijańska ludzi dorosłych a misja duszpasterska Kościoła, „Studia Gdańskie” 23 (2008), s. 215-236.

39 Por. A. Kapusta, Pojęcie choroby psychicznej w fenomenologicznej perspektywie, „Studia Metodologiczne" 30 (2013), s. 41-61. A. Kapusta, O roli myślenia technologicznego w psychiatrii współczesnej, „Diametros” 44 (2015), s. 45-55.

40 A. Kępiński, Poznanie chorego, Warszawa 1978, s. 17-18. 
sensu swojego istnienia ${ }^{41}$. Zakorzenienie w Bogu i powszechne powołanie do realizowania siebie w odniesieniu do Niego zostało jeszcze mocniej podkreślone przez wcielenie Jezusa Chrystusa ${ }^{42}$.

Powyższe przesłanki wskazują na konieczność uwzględniania duchowości osób z zaburzeniem psychicznym podczas ich leczenia oraz ścisłej współpracy duszpasterzy ze specjalistami z zakresu psychiatrii. W tym kontekście, jednym z zadań kapelana szpitalnego lub innego duszpasterza mającego kontakt z takimi pacjentami, jest próba wprowadzenia pomocy duszpasterskiej jako zwyczajnego elementu terapii kompatybilnego z jej całościową strukturą. Znaczącą pomoc w tej kwestii mogą wnieść osoby świeckie spośród personelu medycznego, zaangażowane religijnie lub pracujące jako asystenci pastoralni.

\section{Udział asystentów pastoralnych w przygotowaniu do sakramentu pokuty i pojednania}

Posługa kapelana szpitalnego wobec pacjentów psychotycznych może być niewystarczająca w stosunku do ich potrzeb duchowych, szczególnie w dużych jednostkach medycznych, gdzie hospitalizowanych jest wielu pacjentów. Zadania kapelana powinny skupiać się przede wszystkim na duszpasterstwie sakramentalnym, które jest podstawowym celem każdej aktywności pastoralnej. Osoby z zaburzeniem psychicznym wymagają regularnego, zindywidualizowanego i wydłużonego w czasie przygotowania do korzystania z sakramentów, szczególnie spowiedzi i Eucharystii. To przygotowanie może odbywać się w sposób spontaniczny - poprzez osobisty kontakt pacjenta z wierzącymi przedstawicielami personelu szpitalnego lub zorganizowany - w ramach pracy zespołu wsparcia duchowego złożonego ze świeckich asystentów pastoralnych. Wówczas posługa duszpasterska jest realizowana stopniowo przez przedstawicieli poszczególnych struktur apostolskich, co odzwierciedla

${ }^{41}$ T. Homa, Biblijne koncepcje człowieka. Szkice antropologiczne, w: Docere et educare, red. J. Mółka, G. Łuszczak, Kraków 2008, s. 53-67.

${ }_{42}$ Por. Sobór Watykański II, Konstytucja dogmatyczna o Kościele Lumen gentium, 8, w: Sobór Watykański II, Konstytucje, dekrety, deklaracje, tekst polski, nowe tłum., red. M. Przybył, Poznań 2002 (dalej: LG), s. 109-111. Por. J 3, 16; Mt 10, 28; Dz 17, 28. 
podział na różne grupy towarzyszące Chrystusowi w jego ziemskiej działalności (słuchacze, uczniowie, apostołowie, trzech uczniów - Piotr, Jakub, Jan $)^{43}$.

Asystenci pastoralni w swojej pracy pełnią funkcję pośredniczącą między kapelanem szpitala, będącym osobą duchowną a pozostałymi świeckimi pracownikami danej jednostki medycznej. Konsekwencją takiego usytuowania ich posługi jest konieczność całościowego spojrzenia na pacjenta i jego problemy, z uwzględnieniem kontekstu medycznego i duchowego. Nauczanie Kościoła katolickiego podkreśla konieczność wykorzystania wiedzy z zakresu nauk humanistycznych we wsparciu duchowym, przy jednoczesnym nieabsolutyzowaniu którejkolwiek z dziedzin ${ }^{44}$, gdyż ostateczne wyjaśnienie ludzkiego życia, wraz z jego słabościami i cierpieniem, odnajduje się tylko „w tajemnicy Słowa Wcielonego” ${ }^{45}$. Podstawową formą wsparcia duchowego są wspólna modlitwa oraz obecność wynikająca z tej samej tożsamości wiary. W normalnych warunkach te dwa czynniki wsparcia zapewnia wspólnota parafialna, jednak w przypadku pacjentów psychotycznych ich odniesienie do Kościoła najczęściej jest zachwiane, a potrzeby pomocy duszpasterskiej znacznie większe ${ }^{46}$. Papież Franciszek w adhortacji Amoris laetitia podkreśla konieczność towarzyszenia duchowego wszystkim tym, którzy znajdują się w nieregularnych sytuacjach życiowych, a wśród nich są nie tylko osoby o zachwianym statusie małżeńskim, ale również dotknięte kryzysem lub inną skomplikowaną sytuacją ${ }^{47}$.

Zespoły wsparcia duchowego muszą być do takiej posługi odpowiednio przygotowane - ich członkowie powinni mieć wykształcenie teologiczne i osobiste doświadczenie wiary (tutaj istotna jest współpraca z kapelanem, który jako przedstawiciel instytucji kościelnej będzie mógł

43 Por. H. Langkammer, Uczniowie, grupa dwunastu, apostołowie, „Studia Theologica Varsaviensia" 14 (1976) nr 2, s. 67-84.

${ }^{44}$ Por. J. Szkodoń, Duchowość, między teologia i psychologia, w: Czy dzisiaj można formować bez psychologii, red. M. Kożuch, J. Poznański, Kraków 2002, s. 23-24.

45 Por. LG 54.

46 Por. K. Grzywocz, Współczucie w kierownictwie duchowym, w: Sztuka kierownictwa duchowego, red. J. Augustyn, J. Kołacz, Kraków 2007, s. 588.

47 Por. Franciszek, Posynodalna adhortacja apostolska Amoris laetitia, 19.03.2016, 242249, Kraków 2016. 
w jakimś sensie weryfikować te wymagania). Praca świeckich asystentów pastoralnych przynosi bilateralne korzyści, gdyż stanowi początkowy etap kształtowania wrażliwości religijnej pacjentów oraz dostarcza informacji na temat ich kondycji duchowej, co często jest niezbędne do dalszej posługi duszpasterskiej kapelanów. W pierwszym zakresie działań szczególną korzyść przynoszą pacjentom: modlitwa prowadzona przez świeckich asystentów pastoralnych, zaangażowanie w rozmowę z nimi, aktywne słuchanie, wykazanie zainteresowania ich doświadczeniami, przekaz treści religijnych kształtujących obraz Boga zgodny z Magisterium. Dzięki spełnieniu tych zadań pacjent może rozwijać w sobie nadzieję na wyjście z duchowego kryzysu towarzyszącego chorobie psychicznej oraz otwierać się na osobiste doświadczenie obecności Boga w swoim życiu. Druga grupa aktywności służy opracowaniu informacji duszpasterskiej o pacjencie, a składa się na nią wnikliwa obserwacja prezentowanego przez niego obrazu Boga, analiza jego możliwości komunikacyjnych i zaangażowania religijnego (szczególnie podejmowanych praktyk pobożnych) ${ }^{48}$.

Opisane wyżej zadania są szczególnie istotne w przygotowaniu pacjentów do sakramentu pokuty i pojednania. Dla wielu z nich jest to bardzo trudne doświadczenie, wymagające wielowymiarowego wysiłku duchowego i psychicznego. Podstawową trudnością jest wybaczenie innym, sobie i Bogu (rozwój właściwego obrazu Boga pozwala na dostrzeżenie Jego miłosiernego oblicza i odniesienia do tego obrazu trudnych doświadczeń życiowych). Asystenci pastoralni podczas indywidualnego kontaktu mogą uczyć, na czym polega chrześcijańska postawa wybaczenia, która nie musi równać się ignorancji czy zapomnieniu, ale zgodzie na to, jakim się jest człowiekiem oraz otwarciem perspektywy nadziei na przyszłość ${ }^{49}$. Akceptacja siebie wraz ze swoimi wadami jest kluczowym elementem umożliwiającym dojrzałe przeżywanie wiary. W przypadku pacjentów psychotycznych obraz siebie może być zaburzony w kierunku negatywnym (brak poczucia wartości) lub nadmiernie

\footnotetext{
48 Por. J. Klimek, Duszpasterstwo..., dz. cyt., s. 323-324.

49 Por. J. Lekan, Przebaczenie w optyce miłosierdzia, „Teologia w Polsce” 10 (2016) nr 2, s. 59-77.
} 
pozytywnym (niezauważanie zła) ${ }^{50}$. Ukazanie zewnętrznej perspektywy może stać się pomocne do odkrycia przez pacjenta, kim tak naprawdę jest i umiejętnego przeprowadzenia rachunku sumienia. Dalszym etapem jest otwarcie na zmianę siebie i odpokutowanie tych błędów, które wynikały z uświadomionej, złej woli przygotowującego się do spowiedzi. Polega ono na przekonaniu penitenta przez indywidualny kontakt (rozmowa i towarzyszenie) o możliwości nabycia cnoty wolności przez dobre przygotowanie iprzystąpienie do spowiedzi wraz z warunkami zadośćuczynienia ${ }^{51}$.

Praca zespołu wsparcia duchowego ma też przyziemny, ale niezwykle ważny wymiar ze względu na potrzebę fundamentalnego doświadczenia Kościoła jako wspólnoty (communio-coinonia) gromadzącej się w locum sacrum. Zaangażowanie zespołu ułatwia i często w ogóle umożliwia pacjentom dotarcie do kaplicy i spotkanie z kapelanem szpitalnym, co dla osób z zaburzeniem psychicznym może stanowić poważny problem ze względów proceduralnych (dla pacjentów mających wyjścia poza oddział tylko w towarzystwie personelu), mentalnych (brak świadomości takiej możliwości lub nieuświadomiona potrzeba), emocjonalnych (lęk przed indywidualnym spotkaniem z osobą duchowną lub opuszczeniem „bezpiecznego” miejsca, jakim może być oddział szpitalny), jak i fizycznych (ograniczenia ruchowe pacjentów psychogeriatrycznych).

\section{Zakończenie}

Wsparcie duszpasterskie osób z zaburzeniem psychicznym służy ich powrotowi do całościowej równowagi (dobrostanu), rozumianej także w kategoriach psychicznych i somatycznych. Aby mogło być skutecznie realizowane, potrzeba uwzględnienia indywidualnej sytuacji pacjenta oraz czynników pozaduchowych wpływających na ich szczególne cierpienie, jakie wiąże się z tego rodzaju chorobą. Ważna jest również

${ }^{50}$ Por. D. Kowalczyk, Spowiedź, czyli przekonywania o grzechu i miłości, w: Sztuka spowiadania, red. J. Augustyn, Kraków 2017, s. 77-85.

51 Por. A.J. Skowronek, Poznać prawdę o sobie. Rachunek sumienia z dekalogu, w: Sztuka spowiadania, dz. cyt., s. 589-590. 
zorganizowana współpraca z personelem medycznym opiekującym się pacjentami i osobami zaangażowanymi bezpośrednio $\mathrm{w}$ działania duszpasterskie, takimi jak świeccy asystenci pastoralni. Pomoc duchowa pacjentom psychotycznym powinna być udzielana w sposób stopniowy, zorganizowany i permanentny.

\section{Bibliografia}

Anczewska M., Wciórka J., Umacnianie - nadzieja czy uprzedzenia, Warszawa 2007. Androutsos G., Karamanou M., The hospital institutions of Byzantium and the hospital (Xenon) of Pantokrator monastery in Constantinople, „La Presse Médicale” 41 (2012) no. 1, s. 68-73.

Bachanek G., Psychologia a teologia. Miejsca spotkania w antropologicznej refleksji J. Ratzingera, ,Studia Teologii Dogmatycznej” 1 (2015), s. 31-47.

Baranow S., Ermer A., Dittmann V., Stieglitz R. D., Upośledzenie umysłowe, w: Kompendium psychiatrii, psychoterapii, medycyny psychosomatycznej, red. H.J. Freyberger, W. Schneider, R.D. Steiglitz, Warszawa 2015.

Bilikiewicz A., Klasyfikacja zaburzeń psychicznych i zagadnienia nazewnictwa, w: Psychiatria. Podręcznik dla studentów medycyny, red. A. Bilikiewicz, Warszawa 2009,108-115.

Błeszyński J., Niepełnosprawność intelektualna. Mowa, język, komunikacja, Gdańsk 2013.

Butcher J., Hooley J., Mineka S., Psychologia zaburzeń, tłum. S. Pikiel, A. Sawicka-Chrapkowicz, Sopot 2017.

Cascher M.I., Bess J.D., Pacjent na oddziale psychiatrycznym. Wskazówki praktyczne, tłum. J. Serewa, M. Pokorska, red. D. Dudek, Warszawa 2013.

Cechnicki A., Wojciechowska A., Valdes M., Sieć społeczna a jakość życia osób chorujacych na schizofrenię w siedem lat po pierwszej hospitalizacji, „Psychiatria Polska” 41 (2007) nr 4, s. 527-537.

Centrum Badania Opinii Społecznej, Stosunek do osób chorych psychicznie, Warszawa 2012.

Dębiec J., Opętanie. Próba psychologicznego ujęcia problemu, Kraków 2004.

Draguła A., Duchowość karmi się psychika, w: Między konfesjonałem a kozetka, red. K. Jabłońska, C. Gawryś, Warszawa 2010, s. 13-14.

Franciszek, Posynodalna adhortacja apostolska Amoris laetitia, 19.03.2016, Kraków 2016.

Grzybowski J., Człowiek jako osoba w metafizyce św. Tomasza z Akwinu, „Warszawskie Studia Teologiczne" 16 (2003), s. 201-229.

Hajduk R., Łagodność pastoralna, Kraków 2018.

Hauerwas S., Psychiatric Care: Professional Commitments and Societal Responsibilities, w: On Moral Medicine. Theological Perspectives in Medical Ethics, ed. S.E. Lammesr, A. Verhey, Eerdmans 1989, s. 556.

Hącia A., Psychiatra i jego misja w nauczaniu Kościoła, Lublin 2017. 
Homa T., Biblijne koncepcje człowieka. Szkice antropologiczne, w: Docere et educare, ed. J. Mółka, G. Łuszczak, Kraków 2008.

Jan Paweł II, Encyklika Redemptor hominis,4.03.1979, Wrocław 1994.

Kapusta A., O roli myślenia technologicznego w psychiatrii wspótczesnej, „Diametros” 44 (2015), s. 45-55.

Kapusta A., Pojęcie choroby psychicznej w fenomenologicznej perspektywie, „Studia Metodologiczne" 30 (2013), s. 41-61.

Kępiński A., Poznanie chorego, Warszawa 1978.

KlimekJ., Duszpasterstwo w kobierzyńskiej kapelanii na przestrzeni wieku, Kraków 2019.

Langkammer H., Uczniowie, grupa dwunastu, apostołowie, „Studia Theologica Varsaviensia" 14 (1976) nr 2, s. 67-84.

Lekan J., Przebaczenie w optyce miłosierdzia, „Teologia w Polsce” 10 (2016) nr 2, s. 59-77.

Między konfesjonałem a kozetka, red. K. Jabłońska, C. Gawryś, Warszawa 2010.

Möller H. J., Możliwości i ograniczenia DSM-5 w polepszeniu klasyfikacji i diagnozy zaburzeń psychicznych, „Psychiatria Polska” 52 (2018) 4, s. 611-628.

Odnaleźć wykluczonych, red. J. Dziedzic, J. Klimek, Kraków 2014.

Pismo Święte Starego i Nowego Testamentu w przekładzie z języków oryginalnych. Biblia Tysiąclecia, oprac. Zespół biblistów polskich z inicjatywy benedyktynów tynieckich, wyd. 5, Poznań 2000.

Pochmara-Wysoczyńska Z., Bonifratrzy i ich postugiwanie, Kraków 2017.

Przybyłowski J., Wychowanie i formacja chrześcijańska ludzi dorostych a misja duszpasterska Kościoła, „Studia Gdańskie” 23 (2008), s. 215-236.

Pużyński S., Choroba psychiczna - problemy $z$ definicja oraz miejscem $w$ diagnostyce i regulacjach prawnych, „Psychiatria Polska” 41 (2007) nr 3, s. 299-308.

Rapley M., The social construction of intellectual disability, Cambridge 2004.

Ratzinger J, Zeitfragen und christlicher Glaube. Acht Predigten aus der Münchener Jahren, Würzburg 1982.

Ratzinger J., Prawda w teologii, tłum. M. Mijalska, Kraków 2005.

Seligman M., Walker E., Rosenhan D., Psychopatologia, tłum. J. Gilewicz, Poznań 2017.

Seyda B., Dzieje medycyny w zarysie, Warszawa 1977.

Sobór Watykański II, Konstytucja dogmatyczna o Kościele Lumen gentium, w: Sobór Watykański II, Konstytucje, dekrety, deklaracje, tekst polski, nowe tłum., red. M. Przybył, Poznań 2002, s. 104-166.

Sozańska D., Między fascynacją a dystansem. Społeczny odbiór osób chorych psychicznie a ich wizerunek w kulturze masowej - analiza wybranych przypadków, „Labor et Educatio" 2 (2014), s. 105-117.

Spidlik T., Rupnik M., Teologia pastoralna. Duszpasterstwo na nowe czasy, przeł. K. Stopa, Kraków 2010.

Szkodoń J., Duchowość, między teologia i psychologia, w: Czy dzisiaj można formować bez psychologii, red. M. Kożuch, J. Poznański, Kraków 2002, s. 23-24.

Sztuka spowiadania, red. J. Augustyn, Kraków 2017.

Sztuka kierownictwa duchowego, red. J. Augustyn, J. Kołacz, Kraków 2007. 
Tyszkowa T., Jarema M., Między zdrowiem a schizofrenia, „Psychiatria Polska” 47 (2016) nr 4, s. 587-597.

Ucok A., Brohan D., Sartorius N., Leese M., Yoon C., Anticipated discrimination among peaple with schizophrenia, „Acta Psychiatrca Scandinaviensis” 1 (2011) nr 125, s. 77-83.

Urbański S., Nieskończoność Boga w mistycznym zjednoczeniu, „Studia Theologica Varsaviensia" 51 (2013) $\mathrm{nr}$ 2, s. 17-34.

WHO, Fact sheets on sustainable development goals: health target; Mental Health, http:// www.tpn.org.pl/czytelnia/blog-andrzeja/rozpowszechnienie-chorob-psychicznych-w-europie-i-na-swiecie/ (18.04.2020).

WHO, ICD-11. International Classification of Diseases 11th Revision: https://icd.who. int/browse11/l-m/en (22.04.2020).

Zegnas L., Victor B., Conceptual Issues in history of Psychiatry, w: Review of Geeral sychiatry, ed. H.H. Goldman, Los Altos 1984. 